ISTILAH KEKERABATAN DALAM MASYARAKAT BANYUWANGI

\title{
TERMS OF KINSHIP IN THE BANYUWANGI SOCIETY
}

\author{
Puspa Ruriana \\ Balai Bahasa Jawa Timur \\ Jalan Siwalanpanji, Buduran, Sidoarjo \\ Pos-el: puspa.ruriana@gmail.com \\ Telp. 081335626848
}

\begin{abstract}
Kinship is a term to mention or greet someone who is bound to ourselves because of descent, blood, and marriage. In the Banyuwangi society, it is known terms of kinship, which is not found in the other society in east Java. The research purposes are to describe the terms of kinship and their functions to Banyuwangi society. The problem of the research is how the using of the terms kinship and the function in the daily using in Banyuwangi society. The method of the research is participant observation. Padan method is used to analyzes data which are found. Data are colected by interviewing the informants and also it is supported by recording and writing technique. Data is analyzed using kinship system theory. Kinship terms in the Banyuwangi society can be grouped in to three, the kinship terms because of direct line of descent, kinship terms because of indirect line of descent, and kinship terms because of marriage. The function of the terms kinship in the Banyuwangi society in addition to showing kinship relations, it also functions claimed to be brothers.
\end{abstract}

Keywords: the terms, kinship, Banyuwangi society

\begin{abstract}
Abstrak
Istilah kekerabatan adalah istilah untuk menyebut atau menyapa orang yang terikat kepada diri sendiri karena hubungan keturunan, darah, atau perkawinan. Dalam masyarakat Banyuwangi dikenal istilahistilah kekerabatan yang tidak ditemukan pada masyarakat lain di Jawa Timur. Penelitian ini bertujuan untuk mendeskripsikan istilah kekerabatan dan fungsinya bagi masyarakat Banyuwangi. Masalah dalam penelitian ini adalah bagaimanakah penggunaan istilah kekerabatan beserta fungsinya dalam pemakaian sehari-hari masyarakat Banyuwangi? Metode penelitian yang digunakan adalah metode simak dengan teknik libat dan cakap. Metode padan digunakan untuk menganalisis data yang ditemukan. Data dikumpulkan melalui wawancara langsung dengan para informan dengan dibantu teknik rekam dan catat. Data dianalisis dengan menggunakan teori sistem kekerabatan. Istilah kekerabatan dalam masyarakat Banyuwangi dapat dikelompokkan ke dalam tiga kelompok, yaitu istilah kekerabatan berdasarkan garis keturunan langsung, istilah kekerabatan berdasarkan garis keturunan tidak langsung, dan istilah kekerabatan karena adanya perkawinan. Dilihat dari segi fungsi istilah kekerabatan dalam masyarakat Banyuwangi selain untuk menunjukkan hubungan perkerabatan, juga berfungsi untuk nyedol or (mengaku saudara).
\end{abstract}

Kata Kunci: istilah, kekerabatan, masyarakat Banyuwangi

\section{Pendahuluan}

Istilah kekerabatan adalah istilah untuk menyebut atau menyapa orang yang terikat kepada diri sendiri karena hubungan keturunan, darah, atau perkawinan. Istilah kekerabatan bersifat universal dan pasti dimiliki oleh semua bahasa di dunia. Chaer (1997: 99) menyebutkan kata nama perkerabatan, yaitu kata-kata yang menunjukkan 
hubungan kekerabatan atau keluarga dengan pihak diri pertama, misalnya ayah, ibu, nenek, paman, kakak, adik, bapak, dan Saudara. Kata-kata nama perkerabatan ini dapat berfungsi sebagai diri orang pertama, orang kedua, dan orang ketiga dalam suatu pertuturan. Kata-kata ini digunakan untuk menyatakan keakraban (di dalam keluarga), sopan santun, dan hormat (terhadap orang di luar keluarga), dan menampilkan suasana formal (dalam pembicaraan dinas).

Istilah kekerabatan yang muncul sangat dipengaruhi oleh budaya dan tentunya sangat dipengaruhi oleh bahasa yang dimiliki oleh masyarakat setempat. Begitu pula istilah kekerabatan pada masyarakat Banyuwangi, memiliki istilahistilah kekerabatan yang khas dibandingkan masyarakat lainnya di Jawa Timur.

Masyarakat Banyuwangi berlokasi di ujung Timur Pulau Jawa dengan luas wilayah sekitar $5.782,50 \mathrm{~km}^{2}$. Secara administratif, Banyuwangi merupakan bagian dari Provinsi Jawa Timur. Wilayahnya terdiri atas 24 kecamatan, yakni kecamatan Wonorejo, Giri, Glagah, Banyuwangi, Kabat, Singojuruh, Rogojampi, Muncar, Genteng, Srono, Gambiran, Songon, Bangurejo, Purwoharjo, Tegal Dlimo, Pesanggaran, Kalibaru, Glenmore, Sengon, Cluring, Licin, Siliragung, dan Pakis (Ruriana: 2016).

Secara kebahasaan, masyarakat Banyuwangi sehari-hari menggunakan bahasa yang mereka sebut sebagai bahasa Blambangan. Di samping itu, masyarakat Banyuwangi juga kerap menggunakan bahasa Jawa sebagai bahasa pergaulan mereka sehari-hari, terutama yang berada di daerah perkotaan. Selain itu, tidak sedikit pula yang menggunakan bahasa Indonesia dalam berbagai peristiwa tutur. Hal itu tidak lepas dari pengaruh media, baik cetak, audio, audio-visual, dan sosial, serta bahasa pengantar pendidikan di sekolah.

Selama ini penelitian terhadap bahasa yang digunakan masyarakat Banyuwangi masih jarang dilakukan. Hal ini terutama disebabkan adanya anggapan bahwa bahasa yang digunakan oleh masyarakat Banyuwangi hanyalah dianggap dialek dari bahasa Jawa. Walaupun demikian, peneliti merasa ada banyak kekhasan yang dimiliki masyarakat Banyuwangi yang belum banyak diungkap, antara lain penelitian terkait istilah kekerabatan masyarakat Banyuwangi. Untuk itu, penelitian terkait istilah kekerabatan ini perlu untuk dilakukan.

Masalah yang dibahas dalam penelitian ini, yaitu bagaimanakah penggunaan istilah kekerabatan dalam masyarakat Banyuwangi beserta fungsi istilah kekerabatan tersebut dalam penggunaan sehari-hari masyarakat Banyuwangi? Dengan demikian, tujuan penelitian ini adalah untuk mengetahui istilah kekerabatan khas yang dimiliki masyarakat Banyuwangi beserta fungsi istilah kekerabatan tersebut dalam penggunaan sehari-hari.

Kajian istilah kekerabatan sudah cukup banyak dilakukan. Namun, penelitian tersebut umumnya terkait dengan sistem sapaan yang dimiliki dalam suatu bahasa. Selain itu, penelitian yang ditemukan umumnya bersifat kontrastif, yaitu dengan membandingkan istilah kekerabatan dalam dua bahasa yang berbeda. Penelitian tersebut dilakukan Baransano (2014) dengan judul "Istilah Kekerabatan dalam Bahasa Inggris dan Bahasa Kayupulo (Suatu Analisis Kontrastif)". Penelitian sejenis dengan membandingkan istilah kekerabatan dalam dua bahasa juga dilakukan oleh Simboh (2002), Takua (2003), Naman (2007), dan Yulianto (2012). Yang membedakan penelitian ini dengan penelitian-penelitian sebelumnya, yaitu dalam penelitian ini tidak dilakukan perbandingan istilah kekerabatan, tetapi lebih difokuskan pada penggunaan istilah kekerabatan tersebut dan fungsi istilah kekerabatan tersebut bagi masyarakat penggunanya. 


\section{Teori}

Kekerabatan adalah unit-unit sosial yang terdiri dari beberapa keluarga yang memiliki hubungan darah atau hubungan perkawinan. Anggota kekerabatan terdiri atas ayah, ibu, anak, menantu, cucu, kakak, adik, paman, bibi, kakek, nenek, dan seterusnya. Dalam kajian sosiologiantropologi, ada beberapa macam kelompok kekerabatan dari yang jumlahnya relatif kecil hingga besar.

Chaer (1997: 99) menyebutkan kata nama perkerabatan, yaitu kata-kata yang menunjukkan hubungan kekerabatan atau keluarga dengan pihak diri pertama, misalnya ayah, ibu, nenek, paman, kakak, adik, bapak, dan saudara.

Menurut Wardhaugh (1986: 219), sistem kekerabatan merupakan ciri khas umum yang dimiliki oleh setiap bahasa karena kekerabatan memegang peranan sangat penting dalam organisasi kemasyarakatan. Menurutnya, beberapa sistem lebih beragam dibanding yang lain, namun kesemuanya ditentukan oleh beberapa faktor yang berlaku secara umum, yaitu; jenis kelamin, tingkat keturunan, umur, hubungan darah, dan perkawinan. Leech (1974: 236) menguraikan istilah kekerabatan dapat dijelaskan berdasarkan pada jenis kelamin, generasi serta garis keturunan.

Dari pendapat beberapa ahli di atas dapat ditarik simpulan bahwa istilah kekerabatan merupakan istilah yang menunjukkan adanya hubungan kekerabatan atau keluarga karena adanya ikatan darah, baik langsung, tidak langsung maupun adanya ikatan perkawinan.

\section{Metode}

Dalam penelitian ini digunakan metode simak, libat dan cakap (Sudaryanto, 1993). Data dikumpulkan melalui wawancara langsung dengan para informan dibantu dengan teknik rekam dan catat. Wawancara berlangsung dalam suasana yang tidak formal. Demi mendapatkan data yang lengkap, juga digunakan teknik pancing atau elisitasi (Spolsky, 2003:9), yaitu satu strategi untuk memancing atau mengarahkan informan dalam memberi informasi yang diinginkan dalam penelitian.

Menurut Sitorus (2000:86) populasi adalah seluruh unsur atau elemen yang menjadi anggota dalam suatu kesatuan yang akan diteliti, sedangkan sampel adalah wakil dari populasi yang diteliti. Oleh karena itu, digunakanlah sampel untuk mewakili populasi secara keseluruhan. Populasi dalam penelitian ini adalah seluruh pengguna bahasa Blambangan, diutamakan yang berstatus monolingual. Namun, karena sulitnya menentukan keakuratan pengguna bahasa Blambangan monolingual, populasi penelitian ini dibatasi hanya pada daerah relik. Hal ini dilakukan dengan pertimbangan persentase pengguna bahasa Blambangan yang berstatus monolingual di daerah tersebut lebih sedikit dibanding di daerah perkotaan dan desa-desa lain yang bukan relik. Mengingat begitu banyak relik bahasa Blambangan, untuk memudahkan penelitian, populasi pada penelitian ini harus dibatasi. Oleh karena itu, populasi penelitian ini dibatasi pada desa-desa relik di Kecamatan Kabat. Kecamatan Kabat dipilih karena mobilitas masyarakat di kecamatan itu cenderung tidak terlalu tinggi. Dari empat belas desa yang berada di wilayah Kecamatan Kabat dipilih satu desa sebagai sampel, yaitu Desa Bunder. Desa Bunder, dianggap telah mewakili keseluruhan populasi yang ada. Disamping itu, secara kebahasaan keempat belas desa yang berada di Kecamatan Kabat tersebut menggunakan bahasa yang sama.

Sampel yang berkategori sebagai informan penelitian ini merupakan warga asli Desa Bunder. Kriteria informan, yaitu sehat jasmani dan rohani, pengguna bahasa Blambangan aktif, berbahasa ibu bahasa Blambangan, tidak menguasai bahasa lain secara aktif selain bahasa Blambangan, mobilisasi 
rendah, maksimal dua kali dalam setahun pergi ke kota, interaksi dengan suku dan pengguna bahasa lain rendah, maksimal dua kali dalam setahun berkomunikasi dengan orang yang bukan pengguna bahasa Blambangan, tidak terjadi perkawinan silang dengan suku lain, baik dalam keluarga inti maupun keluarga besar, dan minimal berusia empat puluh tahun.

\section{Pembahasan}

Berdasarkan analisis data yang telah dilakukan, istilah kekerabatan dalam masyarakat Banyuwangi dapat dikelompokkan dalam tiga kelompok. Ketiga kelompok tersebut, yaitu istilah kekerabatan yang terjadi karena garis keturunan langsung, istilah kekerabatan yang terjadi karena garis keturunan tidak langsung, dan istilah kekerabatan karena perkawinan. Berikut ini akan dijabarkan satu per satu istilah kekerabatan yang digunakan oleh masyarakat Banyuwangi.

\subsection{Istilah Kekerabatan karena Garis Keturunan Langsung}

Istilah kekerabatan yang terjadi karena garis keturunan langsung adalah istilah kekerabatan yang berasal dari satu garis keturunan secara langsung. Istilah ini terdiri atas generasi sejajar dengan ego, generasi satu tingkat di atas ego, generasi dua tingkat di atas ego, generasi satu tingkat di bawah ego, dan generasi dua tingkat di bawah ego.

\section{a. Generasi Sejajar dengan Ego}

Kerabat yang termasuk pada generasi ini meliputi para kerabat yang berada satu generasi dengan ego atau sejajar dengan ego. Dalam masyarakat Banyuwangi istilah kekerabatan itu adalah sebagai berikut.

\section{Kakang [kakay]}

Istilah kekerabatan kakang [kakay] digunakan untuk menyebut saudara laki-laki dari ego. Kakang [kakay] berarti 'kakak laki-laki'.
Dalam perkembangan, istilah ini mengalami perluasan jangkauan penggunaan. Kakang [kakay] yang semula hanya untuk menyebut kakak lakilaki, kini juga digunakan untuk menyebut laki-laki yang lebih tua yang tidak memiliki hubungan kekerabatan. Kata ini juga digunakan oleh istri kepada suaminya.

Sebutan yang semula hanya untuk laki-laki lebih tua pun meluas kepada laki-laki seumuran, bahkan lebih muda, dengan tujuan menghormati mitra tutur. Akan tetapi, penggunaan kata kakang [kakay] terhadap laki-laki lebih tua, tetapi tidak berkerabat tidak begitu umum dan berlaku hanya di daerah-daerah tertentu saja. Pada beberapa daerah relik ada perasaan malu menggunakan istilah kakang [kakay] kepada laki-laki lebih tua tak berkerabat karena takut dianggap mengakungaku berkerabat, kecuali penutur dan mitra tutur yang telah akrab. Namun, di daerah-daerah tertentu, di wilayah perkotaan, misalnya hal itu tidak berlaku. Istilah kakang [kakay] telah menjadi sapaan pertemanan layaknya sapaan /bung/ dalam bahasa Indonesia. Akan tetapi, umumnya bukan sapaan kakang [kakay] secara utuh yang digunakan melainkan ada penyingkatan menjadi kang [kay] saja. Dalam penggunaannya kata kakang [kakay] dapat muncul dalam dua bentuk, yakni kakang [kakay], dan kang [kay]. Bentuk yang terakhir ini akibat mengalami proses morfologis pelesapan bunyi.

Dalam masyarakat Banyuwangi selain kata kakang [kakay] digunakan kata acak [aca?] untuk menyebut laki-laki lebih dewasa yang memiliki hubungan kekerabatan. Kata acak [aca?] berarti 'kakak laki-laki'. Dalam perkembangannya, istilah ini juga mengalami perluasan jangkauan penggunaan. Dalam penggunaannya kata [aca? $]$ dapat muncul dalam beberapa bentuk, yakni acak [aca?] dan cak [ca?]. Bentuk yang terakhir ini akibat mengalami proses morfologis pelesapan bunyi. 


\section{Embok [ombok ]}

Istilah ini digunakan untuk menyebut perempuan lebih dewasa dari pembicara/penutur yang memiliki hubungan kekerabatan. Embok [əmbək] berarti ‘kakak perempuan'. Istilah [əmbok] digunakan untuk menyebut saudara perempuan dari ego.

Dalam perkembangannya, istilah ini mengalami perluasan jangkauan penggunaan. Embok [əmbok] yang semula hanya digunakan untuk menyebut kakak perempuan, kini juga digunakan untuk meyebut perempuan lebih tua dengan jarak usia tidak terlalu jauh yang tidak terikat hubungan kekerabatan.

Istilah embok [əmbok] yang semula hanya digunakan untuk perempuan lebih dewasa meluas kepada perempuan seumuran, bahkan lebih muda, dengan tujuan menghormati mitra tutur. Dalam penggunaannya kata embok [ombok] dapat muncul dalam beberapa bentuk, yakni [əmbək],

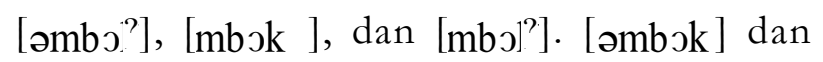
[mbs]'] biasanya muncul pada awal dan akhir klausa dan kalimat. Dua bentuk ini akibat mengalami proses morfologis pelesapan bunyi.

\section{b. Generasi Satu Tingkat di Atas Ego}

Kerabat yang termasuk pada kelompok ini meliputi orang tua kandung ego. Kerabat dalam kelompok ini terdiri atas ayah dan ibu. Dalam masyarakat Banyuwangi dikenal istilah-istilah sebagai berikut.

\section{Apak [apa?]}

Istilah apak [apa?] digunakan untuk menyebut orang tua laki-laki, baik orang tua biologis maupun angkat. Apak [apa?] berarti 'istilah kekerabatan untuk orang tua laki-laki'. Dalam perkembangannya, terutama di perkotaan, istilah ini mengalami perluasan jangkauan penggunaan. Apak [apa?] yang semula hanya digunakan untuk menyebut orang tua laki-laki, baik orang tua biologis maupun angkat, juga menjadi sebutan untuk orang tua laki- laki (dari) ayah dan ibu. Penggunaan, apak [apa? dapat dikatakan minim perubahan. Hinggga kini penyebutan apak [apa?] secara umum hanya digunakan untuk menyebut orang tua laki-laki, baik yang memiliki hubungan biologis maupun tidak.

Dalam penggunaannya, kata apak [apa?] dapat muncul dalam beberapa bentuk, yakni [byapa?], [apa?], dan [pa? ]. Byapak [byapa?] diduga bentuk tua dari [apa?]. Sementara itu, [pa?] hanya muncul pada awal dan akhir klausa dan kalimat.

\section{Emak [əma?]}

Istilah ini digunakan untuk menyebut orang tua perempuan, baik orang tua biologis maupun angkat. Emak [əma'] berarti 'istilah kekerabatan untuk orang tua perempuan'. Dalam perkembangannya, terutama di perkotaan, istilah ini mengalami perluasan jangkauan penggunaan. Emak [əma'] yang semula hanya digunakan untuk orang tua perempuan, baik orang tua biologis maupun angkat, juga untuk menyebut orang tua perempuan (dari) ayah dan ibu. Hinggga kini istilah [əma'] secara umum hanya digunakan untuk menyebut orang tua perempuan, baik yang memiliki hubungan biologis maupun tidak.

Dalam penggunaannya kata emak [oma?] dapat muncul dalam beberapa bentuk, yakni [əma? ] dan [ma? ]. Bentuk yang terakhir ini akibat mengalami proses morfologis pelesapan bunyi.

\section{c. Generasi Dua Tingkat di Atas Ego}

Kerabat yang berada dua tingkat di atas ego, meliputi kakek dan nenek dari ego atau orang tua dari ayah dan ibu ego. Dalam masyarakat Banyuwangi dikenal istilah-istilah sebagai berikut.

\section{Embyah [əmbyah]}

Istilah kekerabatan ini digunakan untuk menyebut kakek atau nenek, baik kakek atau nenek biologis maupun tidak. Embyah [əmbyah] berarti 'istilah kekerabatan untuk menyebut kakek atau nenek'. Dalam perkembangannya, istilah ini 
mengalami perluasan jangkauan penggunaan. Embyah [ombyah] yang semula hanya digunakan untuk kakek atau nenek, baik biologis maupun tidak, juga menjadi istilah yang digunakan untuk menyebut semua orang yang telah lansia, baik lakilaki maupun perempuan, meskipun tidak memiliki hubungan kekerabatan dengan tujuan nyedolor. Nyedolor dalam bahasa Blambangan berarti mengaku saudara.

Dalam penggunaannya secara tutur, istilah embyah [əmbyah] bisa muncul dalam beberapa bentuk, yakni [əmbyah] dan [mbyah]. Bentuk yang terakhir ini akibat mengalami proses morfologis pelesapan bunyi.

Selain istilah di atas, dalam masyarakat Banyuwangi juga dikenal istilah khusus untuk menyebut orang tua dari ayah atau ibu, baik orang tua lakilaki dari ayah atau ibu maupun orang tua perempuan dari ayah atau ibu. Berikut penjelasannya.

\section{Embyah anang [ombyah anay]}

Istilah ini digunakan oleh ego khusus untuk menyebut orang tua laki-laki dari ayah/ibu atau kakek, baik kakek secara biologis maupun tidak. Embyah anang [əmbyah anay] berarti 'istilah kekerabatan untuk kakek'. Dalam perkembangannya, istilah ini mengalami perluasan jangkauan penggunaan. Embyah anang yang semula hanya untuk menyebut kakek, baik biologis maupun tidak, juga menjadi istilah untuk menyebut semua laki-laki lansia meskipun tidak memiliki hubungan kekerabatan dengan tujuan nyedolsr atau untuk merekatkan persaudaraan.

Dalam penggunaannya, istilah embyah anang bisa muncul dalam beberapa bentuk, yakni [əmbyah anay], [mbyah anay], [əmbyah], [mbyah], [anay], dan [nay]. Lima bentuk yang terakhir ini akibat mengalami proses morfologis pelesapan bunyi dan penyingkatan.

\section{Embyah adon [ombyah adon]}

Istilah embyah adon [əmbyah adon] ini digunakan oleh ego khusus untuk menyebut nenek, baik nenek secara biologis maupun tidak. Embyah adon berarti 'istilah kekerabatan untuk nenek'. Dalam perkembangannya, istilah ini mengalami perluasan jangkauan penggunaan. Embyah adon yang semula hanya untuk menyebut nenek, baik biologis maupun tidak, juga menjadi istilah untuk menyebut semua perempuan lansia meskipun tidak memiliki hubungan kekerabatan dengan tujuan nyedol or atau untuk merekatkan persaudaraan.

Dalam penggunaannya secara tutur, [əmbyah adon] bisa muncul dalam beberapa bentuk, yakni [əmbyah adon], [mbyah ad on], [əmbyah], [mbyah], [adon], dan [don]. Lima bentuk yang terakhir ini terjadi akibat mengalami proses morfologis pelesapan bunyi dan penyingkatan.

\section{d. Generasi Satu Tingkat di Bawah Ego}

Kerabat yang berada satu tingkat generasi di bawah ego, yaitu meliputi anak-anak ego. Dalam masyarakat Banyuwangi istilah kekerabatan generasi satu tingkat di bawah ego adalah sebagai berikut.

\section{Tolek [tole?]}

Istilah kekerabatan ini digunakan untuk menyebut anak laki-laki yang masih kecil. Kata tolek [tol $\varepsilon^{\prime}$ ] berarti 'istilah kekerabatan untuk anak laki-laki yang masih kecil'. Berdasar hubungan kekerabatan, selain hubungan bioligis orang tua dan anak, istilah ini juga bisa digunakan oleh orang yang lebih tua kepada orang yang lebih muda atau anak kecil asalkan masih berkerabat. Dalam perkembangannya, istilah ini mengalami perluasan jangkauan penggunaan. Kata tolek [tol $\left.\varepsilon^{\prime}\right]$ yang semula hanya untuk menyebut anak laki-laki yang masih kecil yang terikat hubungan kekerabatan, kini menjadi sapaan untuk anak laki-laki yang masih kecil yang tidak terikat hubungan kekerabatan.

Dalam penggunaannya secara tutur, tolek [tol $\varepsilon^{2}$ ] dapat muncul dalam beberapa bentuk, yakni tolek [tol $\left.\varepsilon^{?}\right]$, dan lek [l $\left.\varepsilon^{?}\right]$. Bentuk yang terakhir ini terjadi 
akibat mengalami proses morfologis pelesapan bunyi.

Dalam masyarakat Banyuwangi selain menggunakan istilah tolek [tole?] untuk menyebut anak laki-laki yang masih kecil juga dikenal istilah cong [coy]. Istilah ini juga digunakan oleh orang tua untuk menyebut anak laki-laki mereka yang masih kecil. Istilah cong [con] dianggap para pengguna bahasa Blambangan bukan merupakan bahasa Blambangan, melainkan merupakan bahasa Madura. Kata ini dimungkinkan merupakan kognet kata / kacong/ pada bahasa Madura. Walaupun demikian, kemunculan istilah cong [coy] dalam masyarakat Banyuwangi sangat terbatas.

\section{Byeng [byey]}

Dalam bahasa Blambangan, byeng [byey] merupakan istilah kekerabatan yang digunakan oleh orang tua untuk menyebut anak perempuan mereka yang masih kecil. Byeng [by \&y] merupakan hasil proses asimilasi penghilangan bunyi dari kata jebyeng [joby\&y] yang berarti 'istilah kekerabatan untuk anak perempuan kecil'.

Berdasarkan hubungan kekerabatan, selain hubungan biologis orang tua dan anak, istilah ini juga bisa digunakan orang yang lebih tua kepada orang yang lebih muda atau anak kecil asalkan masih berkerabat. Dalam perkembangannya, istilah ini mengalami perluasan jangkauan penggunaan. Byeng [byey] yang semula hanya untuk menyebut anak perempuan kecil yang terikat hubungan kekerabatan, kini juga untuk menyebut anak perempuan kecil yang tidak terikat hubungan kekerabatan.

Dalam penggunaannya, istilah byeng [byey] hanya muncul dalam satu bentuk, yakni byeng [byen]. Ada sapaan bing [biy] yang merupakan varian dari byeng [byey], tetapi hanya bersifat parole. Selain kata byeng [by $\varepsilon$ ], juga dikenal istilah $n d u k$ [nḍ̂'] yang digunakan oleh orang tua untuk menyebut anak perempuan mereka yang masih kecil. Nduk [ndo'] berarti 'istilah kekerabatan untuk anak perempuan kecil'. Berbeda dengan istilah byeng [byعn], istilah nduk [nḍo?], tidak layak digunakan untuk perempuan usia dewasa. Ditemukan data penggunaan kata nduk [nḍo?] oleh suami kepada istrinya, tetapi dengan frekuensi kemunculan sangat rendah.

Berdasar hubungan kekerabatan, selain hubungan biologis orang tua dan anak, kata ini juga bisa digunakan orang yang lebih tua kepada orang yang lebih muda atau anak kecil asalkan masih berkerabat.

Dalam perkembangannya, kata ini mengalami perluasan jangkauan penggunaan. Nduk [nḍo?] yang semula hanya digunakan untuk anak perempuan yang masih kecil yang terikat hubungan kekerabatan, kini juga digunakan untuk menyebut anak perempuan yang masih kecil yang tidak terikat hubungan kekerabatan.

Masyarakat Banyuwangi selain menggunakan istilah byeng [byøy] dan nduk [nḍU] untuk menyebut anak perempuan yang masih kecil dikenal pula neng [ney]. Istilah neng [ney] ini digunakan oleh orang tua untuk menyebut anak perempuan mereka yang masih kecil. Neng [ney] berarti 'sapaan untuk anak perempuan kecil'. Istilah Neng [ney] dianggap para pengguna bahasa Blambangan berasal dari bahasa Sunda. Dimungkinkan merupakan kognet kata neng [ney] pada bahasa Sunda. Walaupun demikian, kemunculan istilah neng [ney] dalam masyarakat Banyuwangi sangat terbatas.

\section{e. Generasi Dua Tingkat di Bawah Ego}

Istilah kekerabatan yang berada pada generasi dua tingkat di bawah ego, meliputi anak dari anak ego. Dalam masyarakat Banyuwangi istilah kekerabatan generasi dua tingkat di bawah ego adalah sebagai berikut.

\section{Putau [putaw]}

Putau [putaw] merupakan istilah kekerabatan yang digunakan untuk menyebut anaknya anak. 
Kata putau [putaw] berarti 'istilah kekerabatan untuk anaknya anak atau cucu'.

Dalam masyarakat Banyuwangi tidak ada perbedaan penyebutan untuk menyebut anaknya anak, baik untuk penyebutan anaknya anak atau cucu laki-laki maupun penyebutan anaknya anak atau cucu perempuan. Baik cucu laki-laki maupun cucu perempuan hanya digunakan satu istilah, yaitu putau [putaw].

Kata putau [putaw] dianggap bukan berasal dari budaya masyarakat Banyuwangi, melainkan berasal dari budaya Jawa. Umumnya, kata ini digunakan pada masyarakat yang tinggal di perkotaan.

\subsection{Garis Keturunan Tidak Langsung}

Istilah kekerabatan berdasarkan garis keturunan tidak langsung adalah kekerabatan yang memperhitungkan para kerabat yang berasal dari nenek moyang yang sama, tetapi bukan berasal dari satu garis keturunan langsung. Istilah ini terdiri atas kerabat yang berada satu tingkat di atas ego dan kerabat yang berada satu tingkat di bawah ego.

\section{a. Kerabat yang Berada Satu Tingkat di Atas Ego}

Kerabat yang berada satu tingkat generasi di atas ego karena garis keturunan tidak langsung, meliputi paman atau bibi. Dalam masyarakat Banyuwangi istilah kekerabatan generasi satu tingkat di atas ego adalah sebagai berikut.

\section{Uwyak [uwya?]}

Istilah moyak [uwya'] merupakan istilah yang digunakan untuk menyebut kakak laki-laki atau perempuan (dari) ayah maupun ibu. Uwyak [uwya?] berarti istilah kekerabatan untuk kakak laki-laki maupun perempuan (dari) ayah maupun ibu'. Seiring dengan perkembangan, istilah ini mengalami perluasan jangkauan penggunaan. Uwyak [uwya?] yang semula hanya untuk menyebut kakak laki-laki maupun perempuan dari ayah maupun ibu, juga menjadi sebutan untuk laki-laki dan perempuan seumuran ayah dan ibu meskipun tidak memiliki hubungan kekerabatan dengan tujuan nyedol or atau mengaku saudara.

Dalam penggunaannya uwyak [uwya'] dapat muncul dalam beberapa bentuk, yakni [uwya?] dan [wya']. Bentuk yang terakhir ini akibat mengalami proses morfologis pelesapan bunyi. Dalam penggunaannya sehari-hari kata unyak [uwya'] memiliki variasi penggunaan, yaitu uwyek [uwy $\varepsilon^{?}$ ]. Dalam penggunaannya secara tutur, istilah uwy $\varepsilon k$ [uwyek] bisa muncul dalam beberapa bentuk, yakni [uwy $\varepsilon k]$ dan [wy $\varepsilon \mathrm{k}$ ]. Bentuk yang terakhir ini akibat mengalami proses morfologis pelesapan bunyi.

Selain istilah di atas, untuk menyebut saudara laki-laki ataupun perempuan (dari) ayah maupun ibu, dalam masyarakat Banyuwangi juga dikenal istilah khusus untuk menyebut kakak laki-laki ayah maupun ibu dan ada istilah khusus untuk menyebut kakak perempuan ayah maupun ibu. Selain itu, dalam masyarakat Banyuwangi dikenal pula istilah khusus untuk menyebut adik laki-laki ayah maupun ibu dan ada istilah khusus untuk menyebut adik perempuan ayah maupun ibu. Berikut penjelasannya.

\section{Pak Uwy $\varepsilon$ [ [pa uwy $\varepsilon$ ]}

Pak Uwy khusus untuk menyebut kakak laki-laki (dari) ayah maupun ibu. Pak uwyck [pa? uwy $\varepsilon \mathrm{k}]$ berarti 'istilah kekerabatan untuk kakak laki-laki (dari) ayah maupun ibu'. Dalam perkembangannya, istilah ini mengalami perluasan jangkauan penggunaan. Pak uwy $\varepsilon k$ [pa' uwy $\varepsilon \mathrm{k}$ ] yang semula hanya digunakan untuk menyebut kakak laki-laki (dari) ayah maupun ibu, juga menjadi sebutan untuk lakilaki seumuran ayah dan ibu meskipun tidak memiliki hubungan kekerabatan dengan tujuan nyedol or. Nyedol or dalam bahasa Blambangan berarti mengaku saudara. Dalam penggunaannya secara 
tutur, istilah pak uwy $\varepsilon k$ [pa? uwy $\varepsilon \mathrm{k}]$ bisa muncul dalam beberapa bentuk, yakni [pa? uwy $\mathrm{kk}]$, [pa?

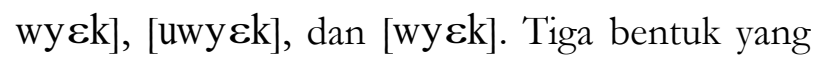
terakhir ini akibat mengalami proses morfologis pelesapan bunyi dan penyingkatan.

Dalam penggunaannya sehari-hari istilah pak. uwyek [pa? uwy $\varepsilon \mathrm{k}]$ memiliki variasi penggunaan, yaitu unyak anang [uwya' anay]. Istilah mmyak anang merupakan istilah khusus yang digunakan untuk menyebut kakak laki-laki (dari) ayah maupun ibu. Dalam perkembangannya, istilah ini juga mengalami perluasan jangkauan penggunaan.

Dalam penggunaannya sebagai tuturan, istilah [uwya? anay] dapat muncul dalam beberapa bentuk, yakni [uwya' anay], [wya' anay], [uwya?], dan [wya']. Tiga bentuk yang terakhir ini akibat mengalami proses morfologis pelesapan bunyi dan penyingkatan.

\section{Uwyak adon [uwya? adon]}

Istilah mnyak adon digunakan khusus untuk menyebut kakak perempuan (dari) ayah maupun ibu. Uwyak adon [uwya' adon] berarti 'istilah kekerabatan untuk kakak perempuan (dari) ayah maupun ibu'. Dalam perkembangannya, istilah ini mengalami perluasan jangkauan penggunaan. Uwyak adon [uwya? adon] yang semula hanya digunakan untuk menyebut, baik kakak perempuan (dari) ayah maupun ibu, juga menjadi sebutan untuk perempuan seumuran ayah dan ibu meskipun tidak memiliki hubungan kekerabatan dengan tujuan nyedol or. Nyedol or dalam bahasa Blambangan berarti mengaku saudara.

Dalam penggunaannya secara tutur, istilah [uwya? adon] dapat muncul dalam beberapa bentuk, yakni [uwya' adon], [wya? adon], [uwya?], dan [adon]. Tiga bentuk yang terakhir ini akibat mengalami proses morfologis pelesapan bunyi dan penyingkatan.

Dalam penggunaan sehari-hari istilah unyak adon [uwya' adon] memiliki variasi penggunaan, yaitu emak uwyck [əma? uwy $\varepsilon \mathrm{k}$ ]. Istilah emak uwy $\varepsilon$ [əma? uwy $\varepsilon k$ ] ini digunakan khusus untuk menyebut kakak perempuan (dari) ayah maupun ibu. Emak uwyck [əma’ uwy ck] berarti 'istilah kekerabatan untuk kakak perempuan (dari) ayah ataupun ibu'.

Dalam penggunaannya secara tutur, kata [əma' uwy \&k] dapat muncul dalam beberapa

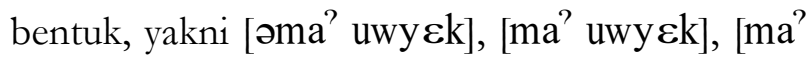

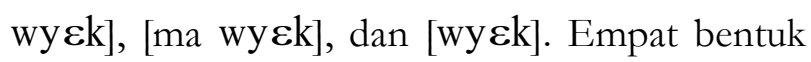
yang terakhir ini akibat mengalami proses morfologis pelesapan bunyi dan penyingkatan.

\section{Paman [paman]}

Istilah paman [paman] digunakan khusus untuk menyebut adik laki-laki (dari) ayah ataupun ibu. Paman [paman] berarti 'istilah kekerabatan untuk adik laki-laki (dari) ayah maupun ibu'. Dalam perkembangannya, istilah ini mengalami perluasan jangkauan penggunaan. Paman [paman] yang semula hanya istilah untuk menyebut adik laki-laki (dari) ayah ataupun ibu, juga menjadi istilah untuk menyebut semua laki-laki lebih tua dengan jarak usia jauh meski tidak memiliki hubungan kekerabatan dengan tujuan nyedol or atau untuk persaudaraan.

Dalam penggunaannya kata [paman] muncul dalam dua bentuk, yakni paman [paman] dan man [man]. Bentuk yang terakhir ini akibat mengalami proses morfologis pelesapan bunyi dan penyingkatan.

Selain dikenal istilah paman [paman] untuk menyebut adik laki-laki (dari) ayah ataupun ibu dikenal pula pak adek [ $\mathrm{pa}^{?}$ ade? $]$ untuk menyebut adik laki-laki (dari) ayah ataupun ibu'. Dalam penggunaannya kata pak adek [pa? ade'] bisa muncul dalam dua bentuk, yakni [pa ade? $^{?}$ dan [pa de?]. Bentuk yang terakhir ini akibat mengalami proses morfologis pelesapan bunyi dan penyingkatan.

Selain kedua istilah tersebut di atas, dalam masyarakat Banyuwangi juga dikenal istilah pak 
en эm [pa? ən эm]. Istilah ini juga digunakan untuk menyebut adik laki-laki (dari) ayah ataupun ibu. Akan tetapi, frekuensi kemunculannya sangat minim. Tidak di semua relik pengguna bahasa Blambangan ditemukan istilah ini.

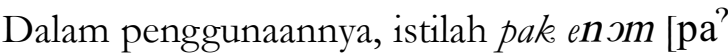
on om] dapat muncul dalam beberapa bentuk, yakni [pa? ənэm], [pa? nom], [ənэm], dan [nom]. Tiga bentuk yang terakhir ini akibat mengalami proses morfologis pelesapan bunyi dan penyingkatan.

\section{Byebek [byebe?]}

Byebek [byebe? merupakan istilah yang digunakan khusus untuk menyebut adik perempuan (dari) ayah ataupun ibu. Byebek [byebe?] berarti istilah kekerabatan untuk adik perempuan (dari) ayah ataupun ibu'. Dalam perkembangannya, istilah ini mengalami perluasan jangkauan penggunaan. Byebek [byebe'] yang semula hanya digunakan untuk menyebut adik perempuan (dari) ayah ataupun ibu, juga digunakan untuk sebutan semua perempuan lebih muda dengan jarak usia yang jauh meski tidak memiliki hubungan kekerabatan dengan tujuan nyedolsr atau mengaku saudara.

Dalam penggunaannya, istilah byebek [byebe? dapat muncul dalam dua bentuk, yakni [byebe? dan [bye']. Bentuk yang terakhir ini akibat mengalami proses morfologis pelesapan bunyi dan penyingkatan.

Selain digunakan istilah byebek [byebe?], untuk menyebut adik perempuan (dari) ayah ataupun ibu juga digunakan istilah emak adek [oma' ade?]. Istilah emak adek [oma' ade'] ini digunakan oleh anak khusus untuk menyebut adik perempuan (dari) ayah ataupun ibu.

Dalam penggunaannya emak adek [oma' ade?] dapat muncul dalam dua bentuk, yakni [oma' ade? dan [ma? ade? $]$. Bentuk yang terakhir ini akibat mengalami proses morfologis pelesapan bunyi dan penyingkatan.
Selain kedua istilah di atas, dalam masyarakat Banyuwangi juga dikenal istilah emak en Jm [əma? ənэm] untuk menyebut adik perempuan (dari) ayah ataupun ibu. Emak en om [əma' on om] berarti 'istilah kekerabatan untuk adik perempuan (dari) ayah maupun ibu'. Dalam penggunaannya secara tutur, istilah [əma' on om] dapat muncul dalam beberapa bentuk, yakni [əma' ən эm], [ma' ən эm], [ma' nom], [ən om], dan [nom]. Empat bentuk yang terakhir ini akibat mengalami proses morfologis pelesapan bunyi dan penyingkatan.

\section{b. Kerabat yang Berada Satu Tingkat di Bawah Ego}

Kerabat yang berada satu tingkat di bawah ego karena garis keturunan tidak langsung, meliputi keponakan, baik keponakan laki-laki maupun keponakan perempuan. Dalam masyarakat Banyuwangi istilah kekerabatan generasi satu tingkat di bawah ego adalah sebagai berikut.

\section{Keponakan [kəponakan]}

Keponakan [kəponakan] merupakan istilah kekerabatan yang digunakan untuk menyebut anak dari saudara laki-laki ataupun saudara perempuan ego. Keponakan [kəponakan] berarti 'istilah kekerabatan untuk menyebut anak dari saudara laki-laki maupun saudara perempuan'.

Dalam masyarakat Banyuwangi tidak ada perbedaan untuk menyebut keponakan laki-laki ataupun keponakan perempuan. Baik keponakan [kəponakan] laki-laki maupun keponakan perempuan untuk menyebutnya hanya digunakan istilah keponakan [kəponakan].

Dalam penggunaannya, istilah keponakan [kəponakan] dapat muncul dalam beberapa bentuk, yakni [kəponakan] dan [ponakan]. Bentuk yang terakhir ini akibat mengalami proses morfologis pelesapan bunyi dan penyingkatan.

\subsection{Istilah Kekerabatan karena Perkawinan}

Istilah kekerabatan karena perkawinan adalah 
istilah kekerabatan yang memperhitungkan para kerabat karena adanya perkawinan. Istilah kekerabatan ini terdiri atas generasi yang berada sejajar ego, generasi satu tingkat di atas ego, dan generasi yang berada satu tingkat di bawah ego.

\section{a. Generasi yang Berada Sejajar Ego}

Istilah kekerabat yang berada sejajar dengan ego karena perkawinan meliputi suami, istri, dan saudara ipar. Dalam masyarakat Banyuwangi istilah kekerabatan generasi yang berada sejajar ego adalah sebagai berikut.

\section{Lakai [lakay]}

Lakai [lakay] merupakan istilah kekerabatan yang digunakan untuk menyebut suami dari ego. Lakai [lakay] berarti 'istilah kekerabatan untuk suami”. Dalam penggunaan sehari-hari seorang istri akan menyebut suaminya dengan mengatakan lakai ison [lakay ison] yang bermakna "suami saya". Namun, dalam penyebutan atau panggilan seharihari kepada suaminya, seorang istri biasa menggunakan panggilan kakang [kakay] atau kang [kay]. Bentuk yang terakhir ini akibat mengalami proses morfologis pelesapan bunyi dan penyingkatan.

\section{Rabai [rabay]}

Rabai [rabay] merupakan istilah kekerabatan yang digunakan untuk menyebut istri dari ego. Rabai [rabay] berarti istilah kekerabatan untuk istri. Dalam penggunaan sehari-hari seorang suami akan menyebut istrinya dengan mengatakan rabai ison [rabay ison] yang bermakna "istri saya". Namun, dalam penyebutan atau panggilan seharihari kepada istrinya, seorang suami biasa menggunakan panggilan dik [di?]. Bentuk dik [di?] ini diduga berasal dari bentuk adik [adi?] yang mengalami proses morfologis pelesapan bunyi dan penyingkatan.

\section{Ipe [ipe]}

Ipe [lipe] merupakan istilah kekerabatan yang digunakan untuk menyebut saudara perempuan atau saudara laki-laki dari istri atau suami dapat juga digunakan untuk menyebut suami atau istri dari kakak atau adik ego. Istilah kekerabatan ipe [lipe] berarti 'istilah kekerabatan untuk menyebut ipar.'

Istilah ipe [lipe] dianggap bukan berasal dari budaya Banyuwangi, melainkan pinjaman dari budaya Jawa. Pengguna istilah tersebut umumnya adalah orang Jawa yang berada dan tinggal di Banyuwangi. Masyarakat Banyuwangi memahami istilah tersebut, tetapi mereka tidak menggunakannya dalam pemakaian sehari-hari. Hal ini terjadi karena masyarakat Banyuwangi telah berakulturasi dengan budaya Jawa. Kedua budaya tersebut telah hidup saling berdampingan.

Dalam budaya Banyuwangi tidak dikenal saudara sambung atau saudara akibat perkawinan sehingga tidak ada istilah khusus untuk menyebut saudara laki-laki maupun saudara perempuan dari suami atau istri. Saudara laki-laki maupun saudara perempuan dari suami atau istri dianggap sama dengan kakak kandung mereka sehingga istilah yang digunakan untuk menyebut saudara perempuan atau saudara laki-laki dari istri atau suami adalah kakang [kakay] untuk saudara laki-laki dan mbok [mbj] ] untuk saudara perempuan. Dalam pemakaian sehari-hari untuk menyebut ipar sering disebut dengan mengatakan saudaranya istri atau suami, dapat juga dengan mengatakan suaminya kakak atau adik atau istrinya kakak atau adik.

\section{b. Generasi yang Berada Satu Tingkat di Atas Ego}

Istilah kekerabatan yang berada satu tingkat di atas ego karena perkawinan, meliputi ibu mertua dan ayah mertua. Dalam masyarakat Banyuwangi istilah kekerabatan generasi satu tingkat di atas ego adalah sebagai berikut.

\section{mertusk [mertus?]}

mertus [mertuэ] merupakan istilah kekerabatan yang digunakan untuk menyebut orang 
tua suami atau istri. Istilah kekerabatan mertus [mertuJ] berarti 'istilah kekerabatan untuk menyebut mertua, baik mertua laki-laki maupun mertua perempuan'. Namun, untuk membedakannya dalam masyarakat Banyuwangi juga dikenal istilah khusus untuk menyebut mertua laki-laki maupun mertua perempuan. Berikut penjelasannya.

\section{Apak mertus [apa? mertus]}

Apak mertus [apa? mertus] merupakan istilah kekerabatan yang digunakan khusus untuk menyebut orang tua laki-laki dari suami atau istri. Istilah kekerabatan apak mertus [apa? mertu于] berarti 'istilah kekerabatan untuk menyebut mertua laki-laki'.

\section{Emak mertus [Ema? mertus?]}

Emak mertus [Ema' mertus] merupakan istilah kekerabatan yang digunakan khusus untuk menyebut orang tua perempuan dari suami atau istri. Istilah kekerabatan emak mertus [Ema? mertuэ] berarti 'istilah kekerabatan untuk menyebut mertua perempuan'.

Istilah-istilah tersebut dimungkinkan merupakan kata pinjaman dari bahasa Jawa. Umumnya, penggunanya adalah masyarakat yang berada dan tinggal di perkotaan.

Bagi masyarakat Banyuwangi untuk menyebut mertua laki-laki umumnya menggunakan sebutan apak [apa?] dan untuk menyebut mertua perempuan dengan sebutan emak [əma]. Hal ini disebabkan masyarakat Banyuwangi menganggap sama antara orang tua kandung dengan mertua mereka. Dalam penyebutan sehari-hari untuk membedakan penyebutan orang tua kandung biasanya diberikan atribut arah untuk membedakannya, misalnya apak kedol [apa' kedol] untuk "bapak selatan" atau emak lor [əma' lor] untuk "ibu utara".

\section{c. Generasi yang Berada Satu Tingkat di Bawah Ego}

Istilah kekerabat yang berada satu tingkat di bawah ego karena perkawinan, meliputi menantu laki-laki dan menantu perempuan. Dalam masyarakat Banyuwangi, istilah kekerabatan generasi yang berada satu tingkat di bawah ego adalah sebagai berikut.

\section{Mantau [mantaw]}

Mantau [mantaw] merupakan istilah kekerabatan yang digunakan untuk menyebut suami atau istri dari anak ego. Mantau [mantaw] berarti 'istilah kekerabatan untuk menyebut anak menantu, baik menantu laki-laki ataupun menantu perempuan'. Dalam masyarakat Banyuwangi tidak ada pembedaan istilah kekerabatan untuk menyebut menantu, baik menantu laki-laki maupun menantu perempuan. Untuk menyebut menantu laki-laki maupun menantu perempuan digunakan satu istilah yang sama, yaitu mantau [mantaw].

\section{Simpulan}

Berdasarkan hasil penelitian yang telah dipaparkan di atas maka disimpulkan bahwa istilah kekerabatan dalam masyarakat Banyuwangi dapat dikelompokkan ke dalam tiga kelompok. Kelompok tersebut, yaitu istilah kekerabatan yang terjadi karena garis keturunan langsung, istilah kekerabatan yang terjadi karena garis keturanan tidak langsung, dan istilah kekerabatan karena adanya perkawinan.

Istilah kekerabatan yang terjadi karena garis keturunan langsung adalah istilah kekerabatan yang berasal dari satu garis keturunan secara langsung. Istilah ini terdiri atas generasi yang sejajar dengan ego, generasi satu tinggat di atas ego, generasi dua tingkat di atas ego, generasi satu tingkat di bawah ego, dan generasi dua tingkat di bawah ego. Istilah kekerabatan berdasarkan garis 
keturunan tidak langsung adalah istilah kekerabatan yang memperhitungkan para kerabat yang berasal dari nenek moyang yang sama, tetapi bukan berasal dari satu garis keturunan langsung. Istilah ini terdiri atas kerabat yang berada di atas ego dan kerabat yang berada di bawah ego. Istilah kekerabatan berdasarkan perkawinan adalah istilah kekerabatan yang memperhitungkan para kerabat karena adanya perkawinan. Istilah kekerabatan ini terdiri atas generasi sejajar ego, generasi satu tingkat di atas ego, dan generasi satu tingkat di bawah ego.

Dilihat dari fungsinya, istilah kekerabatan dalam masyarakat Banyuwangi, selain berfungsi untuk menunjukkan adanya hubungan kekerabatan, dapat juga digunakan untuk nyedolor. Nyedol or dalam bahasa Blambangan berarti mengaku Saudara.

\section{Daftar Pustaka}

Baransano, Astrid. 2014. "Istilah Kekerabatan dalam Bahasa Inggris dan Bahasa Kayupulo (Suatu Analisis Kontrastif)". Jurnal. Fakultas Ilmu Budaya Universitas Sam Ratulangi. Manado.

Chaer, Abdul. 1997. Tata Bahasa Praktis Bahasa IndOnesia (Edisi Revisi). Jakarta: Rineka Cipta.

Leech, Geoffrey. 1974. Semantics: The Study of Meaning, Second Edition. New York: Richard Clay.Ltd.

Naman, Octo Hartanto. 2007. "Istilah Kekerabatan dalam Bahasa Inggris dan Bahasa Nimboran (Suatu Analisis Kontrastif)". Skripsi. Fakultas Sastra Universitas Sam Ratulangi.

Ruriana, Puspa. 2016. "Perbedaan Isolek Osing dan Bahasa Jawa”. Dalam Jurnal Sawerigading. Jurnal Bahasa dan Sastra, Volume 22. NOmor 2. Desember 2016. Hal. 291-302. Balai Bahasa Sulawesi Selatan.
Simboh, Nancy S. 2002. "Istilah Kekerabatan dalam Bahasa Inggris dan Bahasa Tondano (Suatu Analisis Kontrastif)". Skripsi. Fakultas Sastra Universitas Sam Ratulangi.

Sitorus, M. 2000. Berkenalan dengan Sosiologi. Jakarta: Erlangga.

Spolsky, Bernard. 2003. Sociolinguistics. Oxford: Oxford University Press.

Sudaryanto. 1993. Metode dan Aneka Teknik Analisis Bahasa, Pengantar Penelitian Wahana Kebudayaan secara Linguistik. Yogyakarta: Duta Wacana University Press.

Takua, Serly Susanti. 2003. "Istilah Kekerabatan dalam Bahasa Inggris dan Bahasa Pamona (Suatu Analisis Kontrastif)". Skripsi. Fakultas Sastra Universitas Sam Ratulangi.

Wardhaugh, Ronald. 1986. An Introduction to Sociolinguistics. New York: Basil Blackwell.

Yulianto. 2012. "Istilah Kekerabatan dalam Bahasa Inggris dan Bahasa Cina (Suatu Analisis Kontrastif)". Skripsi. Fakultas Sastra Universitas Sam Ratulangi. 